\title{
The Use Of Fixed Assets Management System In Souvenir Centre
}

\author{
Elisa Farida $^{1}$, G. Freddy Koeswoyo ${ }^{2}$, Erdhi Widyarto Nugroho ${ }^{3}$ \\ ${ }^{1,3}$ Department of Information Systems, ${ }^{2}$ Department of Accounting \\ Soegijapranata Catholic University, Semarang, Indonesia \\ 12angelaelisafm@gmail.com, ${ }^{2}$ freddy@unika.ac.id, ${ }^{3}$ erdhi@unika.ac.id
}

\begin{abstract}
Assets have a large role in shoring up a business process in a particular entity. Without fixed assets, a business will be difficult to do its business processes well. Fixed assets owned by Souvenir Centre Group 58 have not been well recorded, from the physical amount or in accounting records. Often the recording of assets manually causes problems due to the possibility of human error. Recording the depreciation of an asset is also a necessity of an entity that runs business processes. Therefore, an application is needed that can replace the manual process to be systemized. The aim of the research to be conducted is to design and develop and implement a fixed asset inventory system at a central store by QR-Code-based "Group 58" and look at the impact it has on the process of manually recording fixed asset inventory. Designing a Fixed Asset Management System at the Souvenir Centre "Group 58", through interviews, a study of company documents, designing Use Case Diagram, ER Diagram, Flowchart, and display design. Once the system is complete, a final interview is conducted with 5 employees/owners of the Souvenir Centre "Group 58" and get the result that the use of the asset management system has a positive impact on the Souvenir Centre "Group 58".
\end{abstract}

Keywords - depreciation, fixed asset, management system.

\section{INTRODUCTION}

An asset is an operational item that is used to support a business process or other entity. An asset can be categorized into two classes: Tangible assets and Intangible assets. An asset has an important role in sustaining the run of business. Thus, a business needs to use and implement asset management.

Group 58 Souvenir Centre is a micro, small, and medium scale business (UMKM) in Semarang, Central Java. Since its establishment in 1988, Group 58 Souvenir Centre has already had its physical store spread in seventeen locations in Central Java. Nonetheless, Group 58 Souvenir Centre has not done the assets recording completely and regularly.

Most fixed assets owned by Group 58 Souvenir Centre are electronic devices. Yet, the total of devices has not been recorded completely in accounting records. Whereas fixed assets that are used for any operational business have an original useful life and an economic life which can be used to calculate and concede depreciation. Depreciation is a must to be recorded and conceded because fixed assets are going to drop their residue value within years ahead. [1]

Technology developments cause a change in an activity pattern that happened in the main activity. A change in humans' role in a business process from executor to organizer makes any organization consider the run of their business. It contradicts the use of a recording system done manually. Therefore, it is important to do innovations and adjustments by using technology as support. The use of a system for helping the run of business can be the answer to the challenges. [2]

The aim of the research to be conducted is to design and develop and implement a fixed asset inventory system at a central store by QR-Code-based "Group 58" and look at the impact it has on the process of manually recording fixed asset inventory. 


\section{LITERATURE}

Asset Management is an important component of an organization. Asset management provides a general understanding of an asset which is an item that has economic exchange value, commercial value, or exchange value owned by a business entity, institution, or individual. [3]

In a broader sense, according to Danylo, N.H. and A. Lemer is "a methodology to efficiently and equitably allocate resources amongst valid and competing goals and objectives". Kaganova and McKellar define asset management as: "Property asset management can be defined as the process of decision making and implementation relating to the acquisition, use, and disposal of real property" [4]

The purpose of asset management according to [5] are as follows: Knowing the number of assets owned by an organization, knowing the location and data of each asset owned by an organization completely and specifically, helping oversee assets that have specific handling, knowing and maximize the performance of assets owned, and assist in planning the use of assets in the future.

Quoted from PSAK 16 [6], Fixed assets are tangible assets that: (a) are held for use in the production or supply of goods or services for rental to other parties, or administrative purposes; and (b) expected to be used for more than one period.

According to [7] Depreciation is the allocation of the acquisition cost of a fixed asset over the lifetime of the asset. The amount that can be depreciated is the difference between the acquisition price and the residual value, or what is meant is the value of the asset at the end of its life.

QR-Code stands for Quick Response Code, this code is designed to be readable by cameras compared to UPC barcodes which must use a laser. QR-Codes work in a similar way to UPC barcodes, the data is organized in the form of patterns that can be decoded. This data can contain anything, such as a URL for a website, or an item's primary keycode [8].

\section{METHOD}

The research was accomplished in Group 58 Souvenir Centre, a micro, small, and medium-scale business (UMKM) located in Walisongo Tugu Street 426 Semarang.

The research used both qualitative and quantitative methods. The writer used interviews, observation, and documents collecting for the data collection. The interview was done to gain the data related to the ongoing business with its technical problems that happened during the run of the business. The observation was done to figure out the company's characteristics to know if it would make an impact on the soon-to-becreated system.

The writer used the Systems Development Life Cycle method for the data analysis which included problem determination is the author formulates problems that occur in the research object and looks for solutions that are relevant to the condition of the research object, system design i.e. the author makes a system design consisting of the creation of a use case diagram, Entity Relationship Diagram, Flowchart and the appearance of the system to be built. The last stage is implementation, i.e. the author conducts further research related to changes that occur after the use of the built system.

\section{RESULTS AND DISCUSSION}

In general, the business processes that will be assisted with this fixed asset system have a flow that starts from buying assets, recording assets in accounting, adding asset data, printing QR-Codes for asset markers, followed by adjustments to asset conditions such as mutation and deletion of assets. The results of this fixed asset application will produce a report on the number of physical fixed assets, detailed information on each type of item, and a fixed asset depreciation report.

\section{A. DESIGN}

The first module is to be built in the Fixed Assets Procurement and Movement Module. 
This module is used to apply for the purchase of goods and the movement of goods. This module will help the business process to apply for the purchase and transfer of goods needed due to a shortage of goods. Next is the Fixed Assets Repair and Disposal module. This module is used to apply for repairs of goods and file for deletion of goods. This module will help the business process to apply for repairs of goods that are felt to be damaged (not functioning) or to apply for routine / periodic repairs. Fixed Asset Depreciation Module is used to help users calculate depreciation on an item automatically. This module will help run business processes to speed up and simplify the calculation of the book value of an item. In addition, there is a master data module which is a collection of master data that affects the process of recording fixed assets. This master data module consists of user master data, location master data, unit master data, and fixed asset master data. Figures are presented center, as shown below and cited in the manuscript.

Use Case Diagram design, useful for knowing the access rights of each user. Following the picture above, there are 4 (four) actors or users who have different authority. Each user must log in.

Figure 1 is an image of the use case diagram designed in this study.

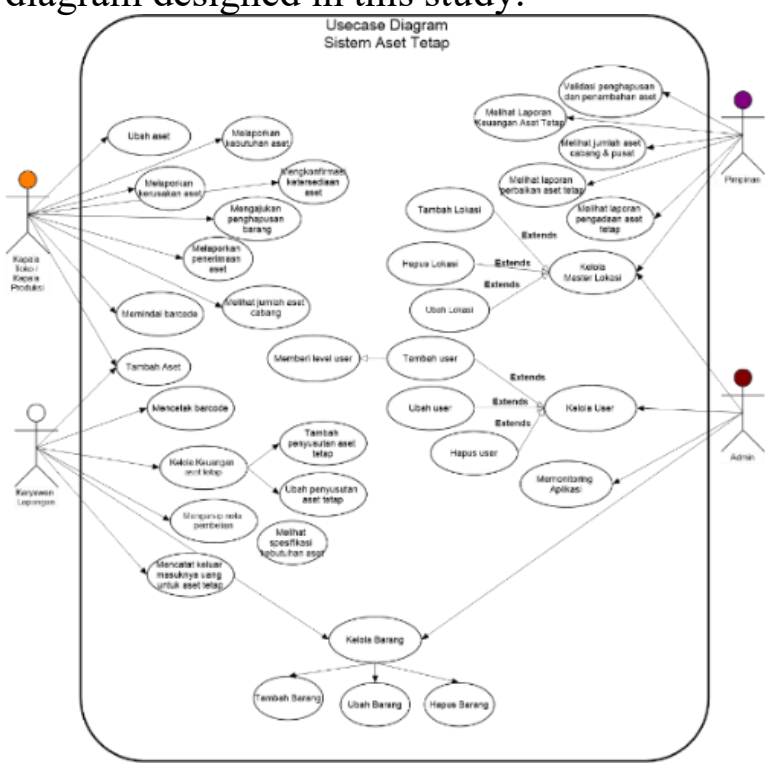

Figure 1: Use case Diagram
Figure 2 is the design of ERD (Entity Relationship Diagram) is used to determine the direction of the data flow of the system to be created.

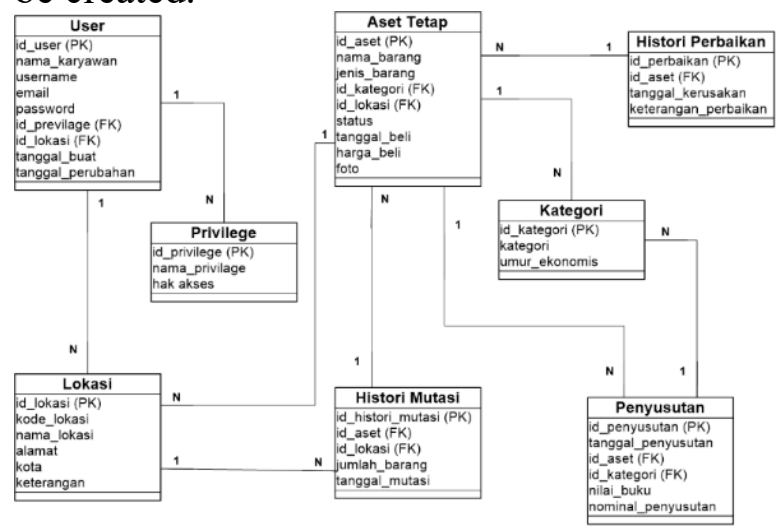

Figure 2: Entity Relationship Diagram

Figure 3 is one of the flowcharts designed to build this asset management system. The flowchart is Flowchart Fixed Asset Report

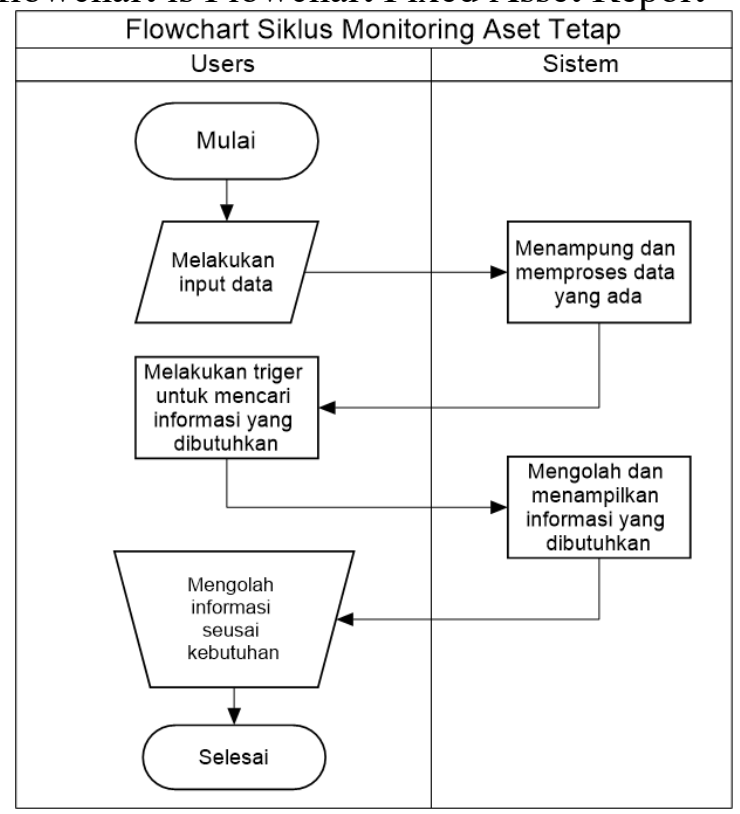

Figure 3: Flowchart Fixed Asset Report

After doing the design, the following is the display result of the system that has been created.

\section{a. Asset Data Page}

Figure 4 is an image of the data display of the assets owned. This page is the first page to run other commands such as insert, update, and delete. 


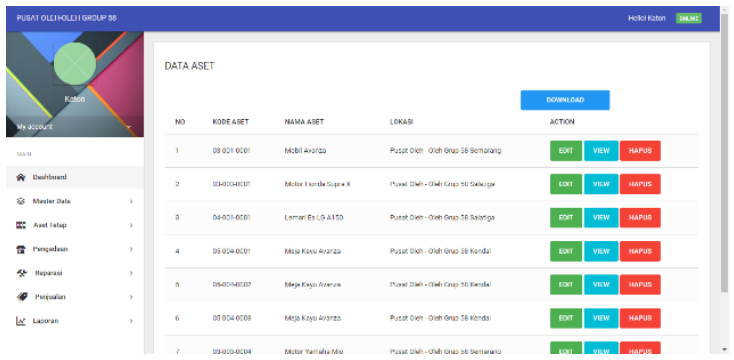

Figure 4: Asset Data Page

b. Asset Detail View page

Figure 5 is an image of the complete asset data display, along with a barcode that marks each asset owned.

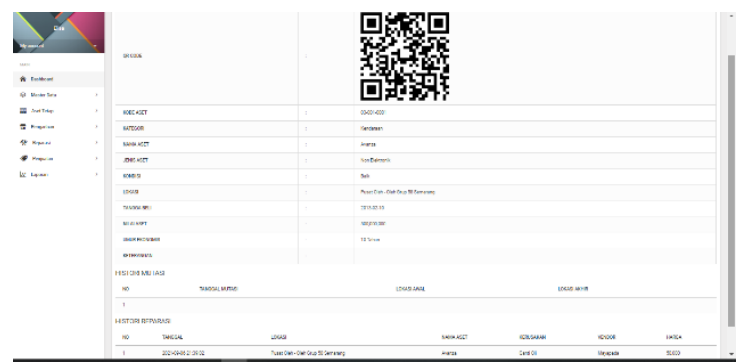

Figure 5: Asset Detail View page

c. Print QR-Code

Figure 6 is the display for running the barcode print command

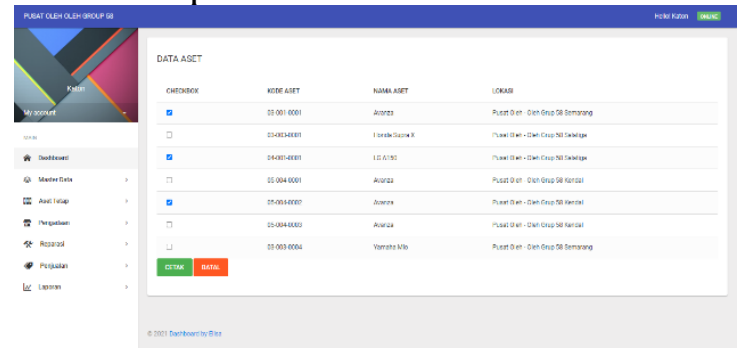

Figure 6: Print QR-Code

d. Barcode display

Figure 7 is a barcode display ready for printing

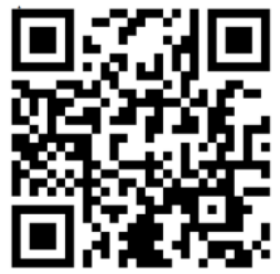

03-003-0001

Honda Supra X

Figure 7: Barcode Display e. Depreciation Index Page

Figure 8 is a preview of the depreciation that has occurred on the assets owned

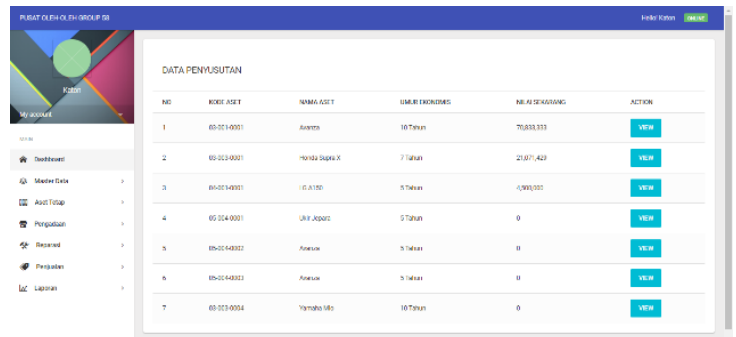

Figure 8: Depreciation Index Page

f. View page Depreciation Details

Figure 9 is a detailed view of the depreciation that has occurred

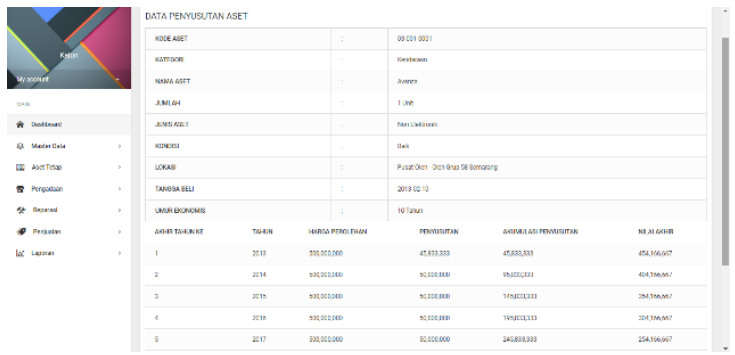

Figure 9: View page Depreciation Details

\section{B. APPLICATION TEST RESULT}

Business testing is carried out using the interview method to several system users from each user level. The author uses the PIECES approach, namely Performance, Information and Data, Economics, Controls and Security, Efficiency and Service.

This Asset Management System has 4 levels of users, therefore the author interviewed 5 (five) users, namely 1 (one) Business Owner, 1 (one) Head of Production, 1 (one) Admin, and 2 (two) people field officer.

Table 1 is the result of interviews that have been carried out with system users.

Table 1: Interview Result

\begin{tabular}{|c|c|}
\hline QUESTION & ANSWER \\
\hline $\begin{array}{l}\text { Can the system } \\
\text { operate a certain } \\
\text { number } \begin{array}{l}\text { of } \\
\text { commands in a }\end{array}\end{array}$ & $\begin{array}{l}\text { This system can execute } \\
\text { multiple commands in } \\
\text { the same and short time. } \\
\text { The command in }\end{array}$ \\
\hline
\end{tabular}




\begin{tabular}{|c|c|c|c|}
\hline & & & \\
\hline \multirow{3}{*}{$\begin{array}{l}\text { short period? } \\
\text { Can the system } \\
\text { perform } \\
\text { cancellation } \\
\text { orders or } \\
\text { requests for a } \\
\text { transaction } \\
\text { quickly? }\end{array}$} & \multirow{3}{*}{$\begin{array}{l}\text { question is to operate } \\
\text { the system at the same } \\
\text { time and with several } \\
\text { commands such as add, } \\
\text { change, delete, cancel, } \\
\text { or view reports. }\end{array}$} & & \\
\hline & & & $\begin{array}{l}\text { operational purposes. } \\
\mathrm{Wi}-\mathrm{Fi} \text { is also available } \\
\text { in some branches. }\end{array}$ \\
\hline & & \multirow{2}{*}{$\begin{array}{l}\text { Is there a } \\
\text { significant } \\
\text { change to this } \\
\text { asset } \\
\text { management } \\
\text { system? }\end{array}$} & $\begin{array}{l}\text { The owner feels a } \\
\text { significant change from } \\
\text { manual recording to } \\
\text { system use. }\end{array}$ \\
\hline \multirow{3}{*}{$\begin{array}{l}\text { Is the system } \\
\text { easy to learn and } \\
\text { understand? }\end{array}$} & \multirow{3}{*}{$\begin{array}{l}\text { This asset management } \\
\text { system is still quite } \\
\text { difficult to understand } \\
\text { because when } \\
\text { socialization between } \\
\text { employees is done using } \\
\text { a smartphone that has a } \\
\text { small display, this } \\
\text { causes steps that should } \\
\text { be easy to be a little } \\
\text { complicated and not } \\
\text { easy to remember. }\end{array}$} & & \\
\hline & & $\begin{array}{l}\text { Are the right of } \\
\text { access in the } \\
\text { system already } \\
\text { anticipating } \\
\text { forms of fraud } \\
\text { and illegal acts? }\end{array}$ & $\begin{array}{l}\text { Features that can be } \\
\text { accessed by each user } \\
\text { are well set up with } \\
\text { some notes and } \\
\text { adjustments, }\end{array}$ \\
\hline & & $\begin{array}{l}\text { Is it in the } \\
\text { maintenance of } \\
\text { the system, the } \\
\text { company has }\end{array}$ & $\begin{array}{l}\text { By Group } 58 \text { has plans } \\
\text { to use this system in the } \\
\text { future, system } \\
\text { maintenance and costs }\end{array}$ \\
\hline $\begin{array}{l}\text { Can the system } \\
\text { produce what the } \\
\text { company } \\
\text { expects? }\end{array}$ & \multirow{2}{*}{$\begin{array}{l}\text { The resulting } \\
\text { information is good and } \\
\text { easy to access because it } \\
\text { does not involve many } \\
\text { views and forms that } \\
\text { must be filled out. }\end{array}$} & $\begin{array}{l}\text { difficulty both in } \\
\text { terms of cost and } \\
\text { implementation? }\end{array}$ & $\begin{array}{l}\text { are not a calculated } \\
\text { problem, but the } \\
\text { maintenance of this } \\
\text { system needs to be }\end{array}$ \\
\hline $\begin{array}{l}\text { Can the system } \\
\text { produce accurate } \\
\text { information } \\
\text { quickly? }\end{array}$ & & & $\begin{array}{l}\text { followed up and } \\
\text { accompanied in the } \\
\text { implementation process } \\
\text { because users do not }\end{array}$ \\
\hline \multirow[t]{2}{*}{$\begin{array}{l}\text { What obstacles } \\
\text { are faced in } \\
\text { using } \\
\text { system? }\end{array}$} & \multirow[t]{2}{*}{$\begin{array}{l}\text { When entering asset } \\
\text { data for the first time, } \\
\text { because the history data } \\
\text { of the previous asset, } \\
\text { has never been recorded. }\end{array}$} & & $\begin{array}{l}\text { understand very well } \\
\text { about the process of } \\
\text { purchasing hosting, } \\
\text { servers, and domains. }\end{array}$ \\
\hline & & \multirow{3}{*}{$\begin{array}{l}\text { Can the system } \\
\text { help optimize } \\
\text { employee } \\
\text { performance? }\end{array}$} & Employee performance \\
\hline $\begin{array}{l}\text { Can the stored } \\
\text { data be easily } \\
\text { reprocessed to be } \\
\text { converted into } \\
\text { useful } \\
\text { information? }\end{array}$ & $\begin{array}{l}\text { Data - the master data } \\
\text { that is used is easy to } \\
\text { access and get further so } \\
\text { that the data can be used } \\
\text { to make decisions } \\
\text { related to the purchase, } \\
\text { sale, reparation, and } \\
\text { elimination of assets. }\end{array}$ & & $\begin{array}{l}\text { has not been too } \\
\text { significantly felt } \\
\text { changes, because } \\
\text { previously did not use } \\
\text { the system, but this } \\
\text { system is not considered } \\
\text { to be troublesome for } \\
\text { employees because there }\end{array}$ \\
\hline \multirow{3}{*}{$\begin{array}{l}\text { Are the } \\
\text { necessary } \\
\text { resources } \\
\text { (internet } \\
\text { connection, } \\
\text { laptop, and } \\
\text { tablet) available? }\end{array}$} & \multirow{3}{*}{$\begin{array}{l}\text { All users already have } \\
\text { the main resources } \\
\text { needed, namely } \\
\text { smartphones r and } \\
\text { internet connections. } \\
\text { The center Souvenir } \\
\text { Group } 58 \text { also has one- }\end{array}$} & & $\begin{array}{l}\text { are no everyday } \\
\text { transactions related to } \\
\text { fixed assets. }\end{array}$ \\
\hline & & $\begin{array}{l}\text { Do you feel } \\
\text { helped using this } \\
\text { system? }\end{array}$ & $\begin{array}{l}\text { The owner believes that } \\
\text { this system will help the } \\
\text { recording of assets. }\end{array}$ \\
\hline & & Would & With this fixed asset \\
\hline
\end{tabular}




\begin{tabular}{|c|c|}
\hline QUESTION & \multirow{3}{*}{$\begin{array}{l}\text { ANSWER } \\
\text { system, the owner feels } \\
\text { it is helpful to record the } \\
\text { fixed assets owned and } \\
\text { will use the system in } \\
\text { the future. }\end{array}$} \\
\hline $\begin{array}{l}\text { rather use this } \\
\text { system than a } \\
\text { manual system? }\end{array}$ & \\
\hline $\begin{array}{l}\text { Do you want to } \\
\text { use this system } \\
\text { in the future? }\end{array}$ & \\
\hline
\end{tabular}

\section{CONCLUSION}

Based on the research, interview results, and application testing data above, it can be concluded that:

Fixed Asset Management System design at the "Group 58" Souvenir Center, through interviews, studying company documents, designing Use Case Diagrams, ER Diagrams, Flowcharts and designing displays

In general, the system has been running well, starting from entering master data which includes users, locations, units, and fixed assets. In addition, the system has also carried out orders that help monitor the movement and changes of fixed assets, such as Purchases, Movements, Sales, Repairs, and Eliminations. This system can also provide reports on the calculation of depreciation and the final value of a fixed asset.

After conducting interviews with the owner of the "Group 58" souvenir center with several employees from every level of user, it can be concluded that using this Fixed Asset Management System, has had a positive impact on the "Group 58" Souvenir Center, where the use of the system can help monitor the number and movement of fixed assets in their business.

\section{REFERENCES}

[1] Ferianto, A. D. (2020). Implementation of Accounting Policies on Fixed Assets at PT Taspen (Persero) Surabaya Main Branch Office. VOCATIONAL FACULTY. Surabaya: Airlangga University.

[2] Dr. H. Lukman Hakim, M. (2019). Principles - Basic Principles of
Management Information Systems. Jambi: Northeast Script.

[3] Qalby, N. (2017). Web-Based Asset Management Information System Design at Labuang Baji Makassar Hospital. Makassar: Faculty of Science and Technology Uin Alauddin.

[4] Hadinata, A. (2011). Asset Management Teaching Materials. Jakarta: State College of Accountancy. Retrieved from https://docplayer.info/121100-Bahanajar-manajemen-asset.html

[5] Sani, F. (2014). Design of Asset and Inventory Management Information System and Inventory SMK N 7 Padang. Padang: Padang State University.

[6] Financial Accounting Standards Board. (2011). Financial Accounting Standards (SAK) No. 16: Fixed Assets. Jakarta: Indonesian Institute of Accountants.

[7] Handoko, D. (2020). Design and Build Applications for Recording Fixed Assets for Retail Companies. FACULTY OF COMPUTER SCIENCE. Semarang: Soegijapranata Catholic University.

[8] Sidhimantra, I. G. (2017). Utilization Of QR Code for Android-Based Inventory Application Design. Surabaya: Sepuluh Nopember Institute of Technology. 